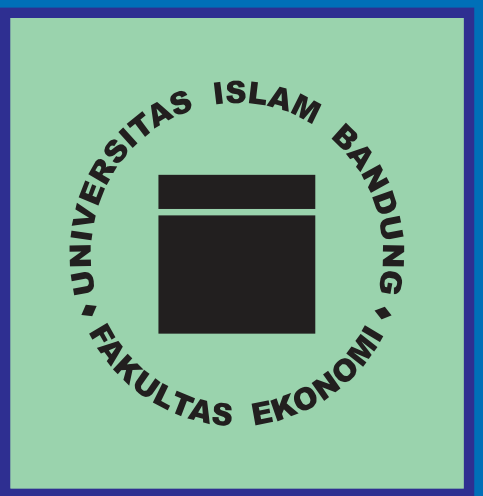

Vol.21 No.2

September 2020

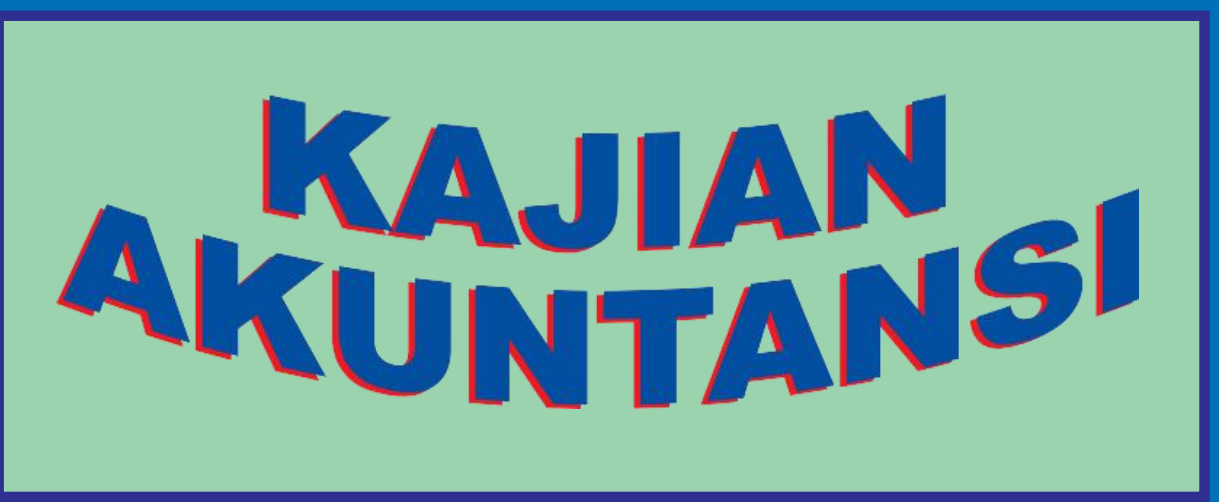

ISSN : 1693 - 0614 e-ISSN : 2581 - 074X
Deliana, Abdul Rahman

Ilham Hidayah Napitupulu, Anggiat Situngkir,

Chairunnisa Arfanni

Edi Sukarmanto, Magnaz Lestira Oktaroza, Karina Nur Astari

Eka Nurmala Sari, Muhyarsyah, Nunung Sri Wahyuni

Nurhayati, Muhammad Kevin Aprilio

Uli Wildan Nuryanto, Masyhudzulhak

Djamil MZ, Achmad Hidayat Sutawidjaya, Ahmad Badawi Saluy.

Riyang Mardini

Annisa Nadiyah

Rahmani

Diamonalisa Sofianty, Lena Herlina.
Efektivitas Audit Internal Pada Perguruan Tinggi Negeri Di Provinsi Sumatera Utara.

Pengaruh Transfer Pricing Dan Profitabilitas Terhadap Tax Avoidance.

Related Party Transaction Memperkuat Pengaruh Political Connection Terhadap Audit Delay?

Pengaruh Sistem Pengendalian Intern Pemerintah Dan Ketersediaan Anggaran Terhadap Efektivitas Penerapan Sistem Informasi Keuangan Daerah Pada Pemerintah Provinsi Dan Kabupaten/Kota Se-Sumatera Utara.

Pengaruh Rasio Solvabilitas Terhadap Kondisi Financial Distress

Implikasi Keunggulan Bersaing Terhadap Kinerja Organisasi Pada Sektor Industri Manufaktur Kimia di Provinsi Banten

Pengaruh Kinerja ICSR Terhadap Readability ICSR Menggunakan Gunning Fog Dan Flesch-Kincaid Indeks Dengan Size, Kinerja Keuangan, Leverage Dan Growth Sebagai Variabel Kontrol.

Dampak Covid-19 Terhadap Harga Saham Dan Kinerja Keuangan Perusahaan

Pengaruh Pengungkapan Corporate Social Responsibility Dan Mekanisme Good Corporate Governance Terhadap Tax Avoidance

Diterbitkan oleh :

ISSN

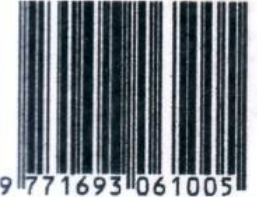

( P 2 U )

Pusat Penerbitan Universitas 


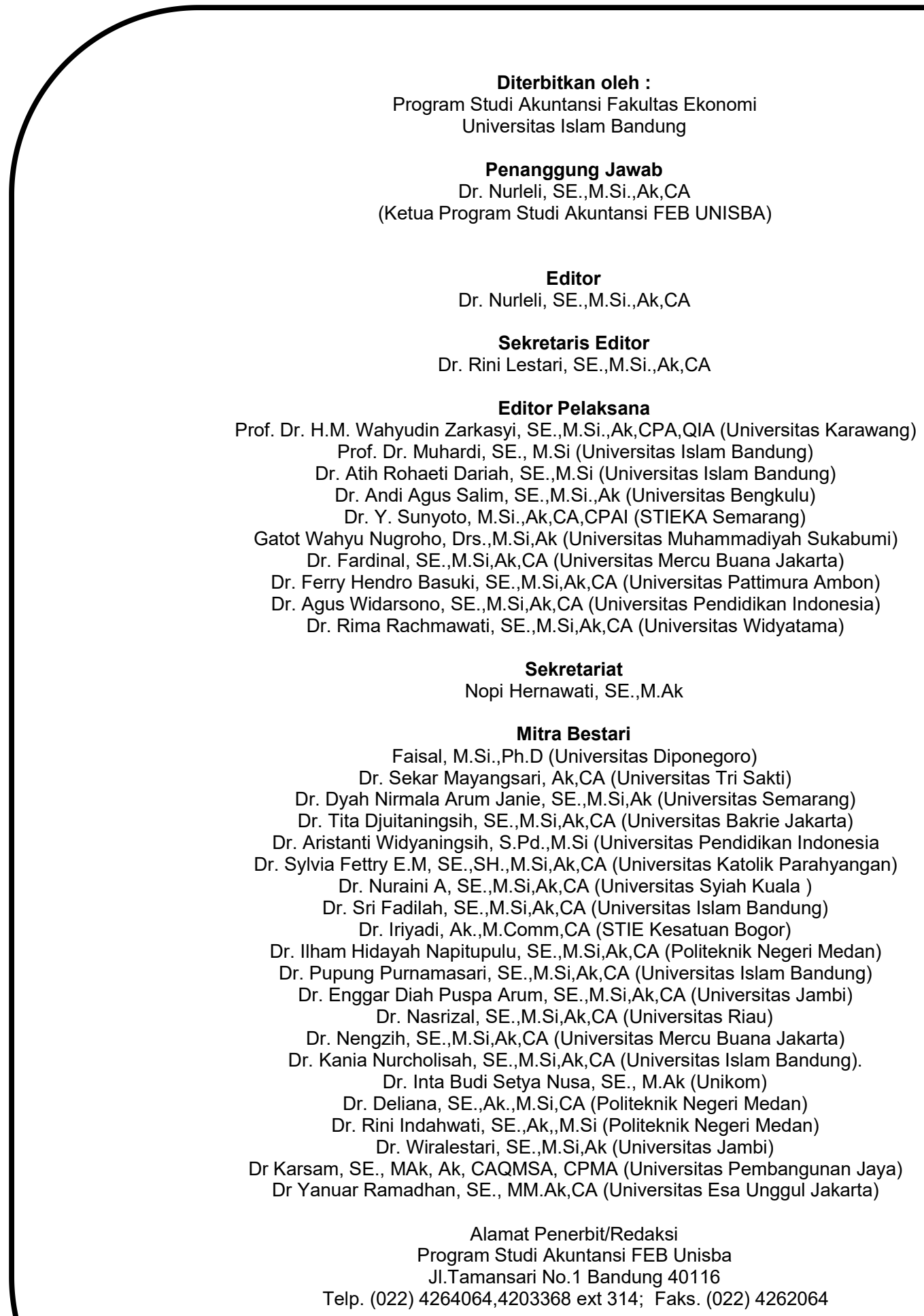

Terbit dua kali dalam setahun : Maret dan September Terbit pertama kali Maret 2003

Redaksi menerima naskah berupa artikel penelitian maupun artikel hasil pengkajian. Pendapat yang dimuat dalam jurnal ini sepenuhnya pendapat pribadi penulis ,

tidak mencerminkan pendapat redaksi,

dan telah disajikan menurut sistematika yang ditetapkan pada halaman akhir jurnal ini . 


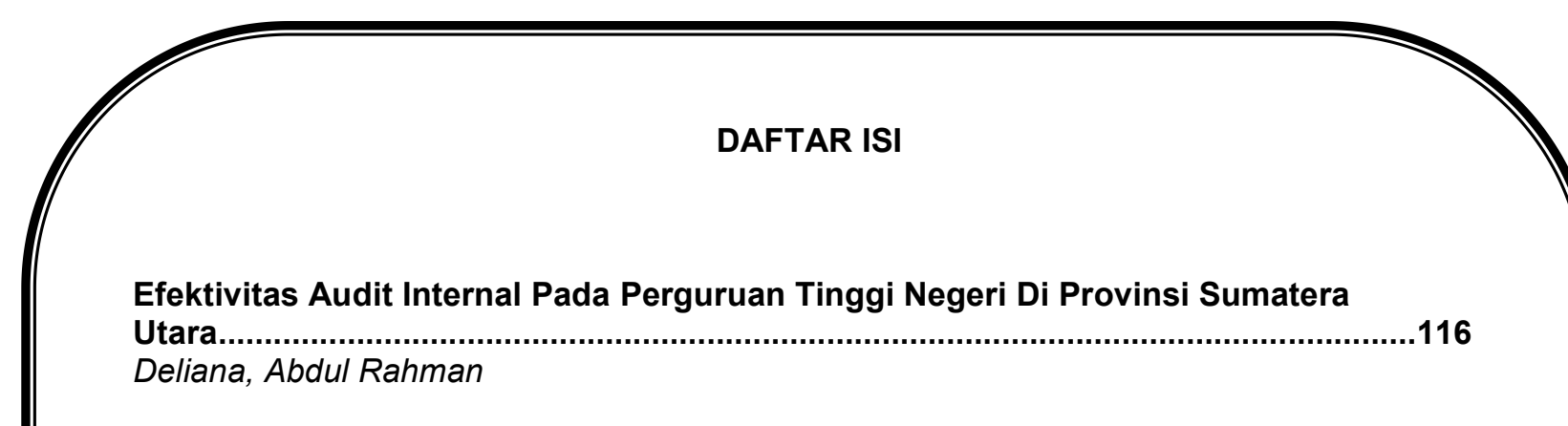

Pengaruh Transfer Pricing Dan Profitabilitas Terhadap Tax Avoidance .126

Ilham Hidayah Napitupulu, Anggiat Situngkir, Chairunnisa Arfanni

Related Party Transaction Memperkuat Pengaruh Political Connection

Terhadap Audit Delay?

Edi Sukarmanto, Magnaz Lestira Oktaroza, Karina Nur Astari

Pengaruh Sistem Pengendalian Intern Pemerintah Dan Ketersediaan Anggaran Terhadap Efektivitas Penerapan Sistem Informasi Keuangan Daerah Pada Pemerintah Provinsi Dan Kabupaten/Kota Se-Sumatera Utara.

Eka Nurmala Sari, Muhyarsyah, Nunung Sri Wahyuni

Pengaruh Rasio Solvabilitas Terhadap Kondisi Financial Distress Nurhayati, Muhammad Kevin Aprilio

Implikasi Keunggulan Bersaing Terhadap Kinerja Organisasi Pada Sektor Industri Manufaktur Kimia di Provinsi Banten.

Uli Wildan Nuryanto, Masyhudzulhak Djamil MZ, Achmad Hidayat Sutawidjaya,

Ahmad Badawi Saluy

Pengaruh Kinerja ICSR Terhadap Readability ICSR Menggunakan Gunning Fog Dan Flesch-Kincaid Indeks Dengan Size, Kinerja Keuangan, Leverage Dan Growth Sebagai Variabel Kontrol

Riyang Mardini

Dampak Covid-19 Terhadap Harga Saham Dan Kinerja Keuangan Perusahaan. Annisa Nadiyah Rahmani.

Pengaruh Pengungkapan Corporate Social Responsibility Dan Mekanisme Good Corporate Governance Terhadap Tax Avoidance.

Diamonalisa Sofianty, Lena Herlina I 


\title{
RELATED PARTY TRANSACTION MEMPERKUAT PENGARUH POLITICAL CONNECTION TERHADAP AUDIT DELAY ?
}

\author{
Edi Sukarmanto \\ Program Studi Akuntansi \\ Universitas Islam Bandung \\ edi06sukarmanto@gmail.com
}

\author{
Magnaz Lestira Oktaroza \\ Program Studi Akuntansi \\ Universitas Islam Bandung \\ ira.santoz@gmail.com
}

\author{
Karina Nur Astari \\ Program Studi Akuntansi \\ Universits Islam Bandung \\ karinanurastari89@gmail.com
}

\begin{abstract}
This study aims to examine the effect of political connection on audit delay and the impact of using related party transactions in moderating the effect of political connection on audit delay. In testing the research objectives, the researcher used multiple regression analysis using a research sample of 59 manufacturing companies or 295 observations for the range of observations in 2013 - 2017.From the results of the tests conducted, the results showed that political connection had an effect on the increase. audit delay. This study also provides results that related party transactions further increase the influence (political connection) on audit delay. The results of this study imply that auditors must be more careful in conducting the audit process on companies that are politically connected and that carry out related party transactions. The high level of business risk that tends to occur in companies that are politically connected and conduct related party transactions gives a negative signal. Therefore, the accounting firm should assign more experienced auditors and auditors who have specialists in certain fields. For further research, it is advisable to use other indicators in measuring related party transactions, such as related purchase transactions and related guarantees.
\end{abstract}

Keywords: Audit Delay, Political Connection, Related Party Transaction.

\begin{abstract}
Abstrak
Penelitian ini bertujuan untuk menguji pengaruh koneksi politis (political connection) terhadap audit delay dan dampak penggunaan transaksi pihak berelasi (related party transaction) dalam memoderasi pengaruh koneksi politis (political connection) terhadap audit delay. Dalam melakukan pengujian terhadap tujuan penelitian tersebut, peneliti menggunakan analisis regresi berganda dengan menggunakan sampel penelitian 59 perusahaan manufaktur atau 295 pengamatan untuk rentang pengamatan tahun 2013 2017. Dari hasil pengujian yang dilakukan, hasil penelitian menunjukkan bahwa koneksi politis (political connection) berpengaruh terhadap peningkatan audit delay. Penelitian ini juga memberikan hasil bahwa transaksi pihak berelasi (related party transaction)
\end{abstract}


semakin meningkatkan pengaruh (political connection) terhadap audit delay. Hasil penelitian ini memberikan implikasi bahwa auditor harus lebih seksama dalam melakukan proses audit pada perusahaan yang terkoneksi secara politis dan yang melakukan transaksi pihak berelasi. Tingginya tingkat risiko bisnis yang cenderung terjadi pada perusahaan yang terkoneksi secara politis dan melakukan transaksi pihak berelasi memberikan sinyal negatif. Oleh sebab itu, kantor akuntan hendaknya memberikan penugasan kepada auditor yang lebih berpengalaman dan auditor yang mempunyai spesialis di bidang tertentu. Bagi penelitian selanjutnya, disarankan untuk menggunakan indikator lain dalam mengukur transaksi pihak berelasi (related party transaction), seperti transaksi pembelian yang berelasi dan jaminan berelasi.

\section{Kata Kunci : Audit Delay, Political Connection, Related Party Transaction.}

\section{PENDAHULUAN}

Koneksi politis (Political Connection) telah terjadi dibanyak negara, tidak terkecuali juga terjadi Indonesia. Umumnya, praktik koneksi politis yang dilakukan oleh perusahaan di suatu negara dapat disebabkan lemahnya perlindungan hukum terhadap pemegang saham minoritas dan terjadinya konsentrasi struktur kepemilikan di suatu perusahaan (Leuz dan Oberholzer-Gee, 2006). Dalam hal adanya koneksi politis, Indonesia telah mempunyai sejarah yang sangat panjang. Ketika dijaman pemerintahan orde baru masih berkuasa (1966-1998), praktik koneksi politis dilakukan pemerintah orde baru dengan menempatkan anggota angkatan bersenjata (baik aktif maupun purnawirawan) untuk memegang posisi jabatan strategis di beberapa perusahaan (Habib, et al., 2017). Memasuki era reformasi (setelah rezim orde baru), koneksi politis tidak lagi didominasi oleh militer, tetapi dipengaruhi oleh para politisi. Tidak jarang para elit politik bertindak sebagai "agen" bagi perusahaan dalam mendapatkan proyek-proyek pemerintah (Fukuoka, 2013).

Rendahnya perlindungan hukum merupakan faktor utama yang menyebabkan perusahaan melakukan praktik koneksi politik. Dengan melakukan koneksi politis, perusahaan mengharapkan adanya perlindungan hukum dari pemerintah demi keberlanjutan usaha yang dilakukan melalui peraturan-peraturan yang dibuat pemerintah. Di samping itu, upaya mendapatkan akses sumber daya juga menjadi pemicu terjadinya koneksi politis. Oleh sebab itu, ketika pasar mengalami hambatan maka stabilitas usaha perusahaan akan tetap terjaga. Kondisi ini menimbulkan kesan bahwa faktor nepotisme sangat mungkin terjadi dan memberi peluang perusahaan melakukan tindakan yang 
merugikan pihak lainnya. Suatu hal yang wajar jika koneksi politis memberikan kesan negatif bagi beberapa pihak sehingga mendapatkan perhatian yang lebih besar dari masyarakat luas. Hal tersebut didukung hasil penelitian Chaney, et al., 2011 bahwa perusahaan yang terindikasi melakukan koneksi politis cenderung melakukan praktik manajemen laba jika dibandingkan perusahaan yang tidak terkoneksi politis. Keadaan ini memberikan gambaran bahwa perusahaan yang terkoneksi politis tidak memiliki tata kelola perusahaan yang baik, sehingga diduga menyimpan risiko bisnis yang besar.

Selain itu juga, untuk memberikan kesejateraan yang lebih baik kepada pemegang saham mayoritas maupun bagi pihak-pihak yang terkoneksi secara politis, perusahaan cenderung mengabaikan kesejahteraan pemegang saham minoritas. Tunneling merupakan praktik yang sering digunakan oleh perusahaan dalam upaya melakukan ekspropriasi (pengambil alihan) hak pemegang saham minoritas bagi kepentingan pemegang saham mayoritas. Oleh sebab itu, perusahaan yang melakukan koneksi politis cenderung melakukan transaksi dengan pihak berelasi atau related party transaction (Berkman, et al., 2009; Qian, et al., 2011). Penelitian sebelumnya menunjukkan bahwa ketika perusahaan melakukan transaksi dengan pihak berelasi lebih banyak melakukan manajemen laba (Chen, et al., 2010; Jian dan Wong, 2010) dan tindakan melakukan manajemen laba juga dilakukan perusahaan saat akan melakukan IPO (Aharony, 2010), sehingga mengakibatkan penurunan kualitas akuntansi (Helaly, 2016).

Apakah hal tersebut memberikan informasi penting bagi auditor dalam melakukan pekerjaan auditnya? Uraian di atas memberikan gambaran bahwa perusahaan yang terkoneksi politis dan melakukan transaksi dengan pihak-pihak berelasi cenderung menyimpan risiko bisnis yang lebih besar. Hasil penelitian Gul (2006) menunjukkan bahwa terjadi peningkatan biaya audit pada perusahaan yang terkoneksi secara politis. Peningkatan biaya audit sangat mungkin terjadi karena indikasi tingginya tingkat risiko bisnis yang dihadapi auditor dalam melakukan pekerjaan audit. Hal menarik ditunjukkan oleh Habib dan Muhammadi (2018) dan Guedhami, et al (2014) bahwa terjadi rentang waktu penyampaian laporan audit yang lebih pendek pada perusahaan yang terkoneksi politis. Digunakannya auditor Big4 oleh perusahaan yang terkoneksi secara politis umumnya dilakukan untuk tetap menjaga kredibilitas perusahaan di mata masyarakat luas. Artinya, semakin tinggi tingkat kompetensi auditor akan mampu menekan terjadinya keterlambatan penyampaian pelaporan. 
Berdasarkan uraian di atas, penelitian ini dimaksudkan untuk menjawab pertanyaan apakah koneksi politis (political connection) memberikan pengaruh terhadap audit delay dan apakah transaksi pihak berelasi (related party transaction) lebih memperkuat pengaruh koneksi politis (political connection) terhadap audit delay. Tidak seperti pada penelitian sebelumnya, penelitian ini tidak terfokus pada auditor Big4. Oleh sebab itu, penelitian ini dimaksudkan untuk mengisi kesenjangan dengan penelitian sebelumnya karena sebatas pengetahuan peneliti belum ada penelitian yang melakukan penelitian tentang hal tersebut.

\section{LANDASAN TEORI DAN PENGEMBANGAN HIPOTESIS}

\subsection{Audit Delay}

Laporan keuangan merupakan salah satu bentuk pertanggungjawaban manajemen kepada pemangku kepentingan perusahaan. Sebagai salah satu sumber informasi yang akan digunakan pemakai dalam pengambilan keputusannya, ketepatan waktu dalam menyampaikan laporan keuangan merupakan faktor utama yang perlu diperhatikan perusahaan. Namun demikian, keterlambatan dalam penyampaian laporan keuangan sangat sulit untuk dihindari perusahaan. Hal ini dapat disebabkan dalam menerbitkan opini terhadap laporan keuangan yang diaudit, auditor akan melakukan proses penyelesaian audit yang sangat krusial. Di samping memerlukan bukti-bukti tambahan terhadap peristiwa-peristiwa di luar periode pelaporan (subsequent event) yang ikut mempengaruhi laporan keuangan periode berjalan, auditor juga memerlukan waktu dalam menyimpulkan hasil audit dalam bentuk opini yang diberikan (Arens, et al., 2017). Adanya rentang waktu penyampaian laporan keuangan auditan tersebut umumnya disebut dengan audit delay. Lamanya audit delay merupakan banyaknya hari yang dihabiskan auditor dalam menyelesaikan proses audit yang dilakukan, terhitung dari tanggal tutup buku perusahaan hingga dikeluarkannya laporan auditor (Ashton, et al., 1987; Bamber, et al., 1993). Dalam ketentuan yang ditetapkan oleh BAPEPAM (2003) menyebutkan bahwa batas toleransi keterlambatan yang diberikan kepada perusahaan untuk menyampaikan laporan keuangan beserta laporan auditor independen adalah 90 hari setelah tanggal tutup buku.

Audit delay merupakan salah satu faktor yang dapat digunakan pihak luar untuk mengukur efisiensi audit, lamanya waktu yang digunakan auditor dapat dianggap sebagai inefisiensi audit (Bamber, et al., 1993). Tentu saja persepsi ini tidak seluruhnya dapat 
dibenarkan. Durand (2019) menyimpulkan bahwa terjadinya audit delay dapat dipengaruhi oleh (1) risiko bisnis auditor (auditor business risk), (2) kompleksitas audit (audit complexity), (3) efektivitas tata kelola klien/perusahaan (corporate governance), (4) jenis opini yang dikeluarkan (audit opinion), dan (5) faktor-faktor lain yang berkaitan dengan pekerjaan lainnya (other work-related factors).

Pertama, risiko bisnis auditor (auditor business risk) merupakan risiko yang akan diterima auditor dari suatu perikatan. Risiko ini sangat berhubungan dengan risiko bisnis yang terdapat dalam aktivitas operasi perusahaan, dan kondisi keuangan perusahaan merupakan faktor utama yang dapat meningkatkan risiko bisnis perusahaan. Perusahaan yang mempunyai risiko bisnis besar akan mengakibatkan pekerjaan audit menjadi lebih lama, karena auditor akan semakin banyak mengumpulkan bukti-bukti untuk mendukung hasil audit. Kedua, kompleksitas audit (audit complexity), faktor ini sangat dipengaruhi oleh ukuran perusahaan yang diaudit. Perusahaan berskala besar akan menyimpan risiko bisnis lebih besar dibandingkan perusahaan berskala kecil. Hal akan mengakibatkan lamanya pekerjaan audit. Ketiga, efektivitas tata kelola perusahaan (corporate governance) juga akan mempengaruhi lamanya auditor dalam melakukan pekerjaan audit. Perusahaan dengan penerapan tata kelola yang baik, akan membentuk tingkat pengendalian internal menjadi lebih baik. Hal ini menimbulkan keyakinan auditor terhadap kondisi laporan keuangan yang dihasilkan perusahaan. Oleh sebab itu, keberadaan tata kelola yang baik akan meminimalisir risiko audit dan prosedur audit yang direncanakan (Cohen dan Hanno, 2000). Keempat, jenis opini yang dikeluarkan (audit opinion). Umumnya perusahaan yang mendapatkan opini wajar tanpa syarat akan cenderung menerbitkan laporan keuangan lebih cepat jika dibandingkan dengan jenis opini lainnya (Durand, 2018). Hal ini mengindikasikan ada/tidaknya masalah penting yang akan menjadi perhatian auditor. Kelima, faktor-faktor lain yang berkaitan dengan pekerjaan lainnya (other work-related factors) dapat berhubungan dengan keberadaan dari extraordinary items yang perlu mendapatkan perhatian lebih dari auditor karena dapat dimanfaatkan perusahaan untuk "menyimpan" sesuatu yang disembunyikan. Banyaknya jenis extraordinary items akan menjadikan pekerjaan audit menjadi lebih lama. 


\subsection{Political Connection}

Koneksi politis (political connection) secara umum merupakan bentuk terjadinya hubungan antara perusahaan dengan para politisi. Koneksi tersebut dapat terjadi apabila setidaknya terdapat satu politisi bertindak sebagai pemegang saham yang mempunyai pengendalian (baik langsung maupun tak langsung) terhadap perusahaan (Faccio, 2006; Habib dan Muhammadi, 2018). Di samping itu juga, koneksi politis dapat juga terjadi apabila salah satu anggota dewan komisaris, dewan direksi merupakan seorang menteri, anggota perlemen, kepala daerah, maupun politisi dari suatu partai (Adhikari, et al., 2006 dan Habib dan Muhammadi, 2018).

Terjadinya koneksi politis antara perusahaan dengan pihak politisi banyak terjadi di beberapa negara, termasuk di dalamnya Indonesia. Terdapat beberapa alasan munculnya koneksi antara perusahaan dengan pihak politisi, diantaranya adalah (1) ketika pasar tidak berjalan dengan baik, perusahaan berharap mendapatkan perlindungan sehingga mengurangi rasa kekhawatiran perusahaan, (2) pemerintah, pejabat pemerintah, maupun politisi dianggap pihak yang mempunyai kekuasaan dalam mengendalikan sumber daya maupun proyek-proyek yang didanai negara, dan (3) perusahaan berharap mendapatkan sumber daya yang diperlukan secara mudah (Li, et al., 2008; Wu, et al., 2012; Habib dan Muhammadi, 2018). Dengan adanya koneksi politis tersebut, perusahaan berharap peraturan-peraturan yang dibuat pemerintah dapat lebih berpihak kepada mereka, lebih mudah mendapatkan akses yang mereka butuhkan, dan mendapatkan jaminan perlindungan. Di sisi yang berbeda, koneksi politis dimanfaatkan oleh para politisi dan pejabat pemerintah untuk tujuan mendapatkan bantuan dana dalam mendukung kampanye, menjaga stabilitas kelompok politis mereka, dan mempertahankan posisi mereka dalam otoritas pemerintahan (Miettinen dan Poutvaara, 2014; Choi dan Thum, 2009).

Timbulnya manfaat yang saling berkorelasi tersebut menimbulkan adanya peluang terjadinya perilaku nepotisme sehingga sering mendapatkan perhatian dan pengawasan yang lebih besar dari pihak-pihak yang berkepentingan. Beberapa penelitian sebelumnya menunjukkan bahwa perusahaan yang terindikasi melakukan koneksi politis rentan akan perbuatan corporate overinvestment (Su, et al., 2013), tunneling (Jiang, et al., 2010), dan manajemen laba (Chaney, et al., 2011) sehingga akan merugikan pemegang saham lainnya. Oleh sebab itu, perusahaan-perusahaan yang terindikasi 
melakukan koneksi politis perlu dilakukan pengendalian dan pemantauan yang lebih besar.

\subsection{Related Party Transaction}

Transaksi-transaksi yang terjadi pada perusahaan umumnya melibatkan pihakpihak eksternal perusahaan, yang secara tidak langsung tidak mempunyai hubungan apapun dengan perusahaan. Walaupun demikian, tidak jarang transaksi yang dilakukan akan melibatkan pihak-pihak internal perusahaan (umumnya disebut sebagai pihak berelasi). Transaksi yang melibatkan pihak-pihak berelasi umumnya disebut sebagai transaksi pihak berelasi (related party transaction). Ikatan Akuntan Indonesia/IAI (2018) menyebutkan bahwa transaksi pihak berelasi merupakan perubahan kepemilikan atas sumber daya, baik berbentuk barang maupun jasa, utang-piutang yang terjadi antara perusahaan pelapor dengan pihak-pihak berelasi. Lebih lanjut dikemukakan oleh IAI (2018) bahwa pihak yang berelasi adalah pihak-pihak yang mempunyai hubungan dengan suatu entitas penyusun laporan keuangan. Umumnya, pihak-pihak yang berelasi tersebut mempunyai pengendalian dan pengaruh terhadap entitas penyusun laporan keuangan.

Dibanyak literatur, masih banyak kontradiksi apakah aktivitas transaksi pihak berelasi memberikan keuntungan atau kerugian bagi para pemangku kepentingan (Yeh, et al., 2012). Peraturan-peraturan yang ada (termasuk didalamya standar akuntansi keuangan) lebih mengatur tentang pengungakapan transaksi pihak berelasi, tetapi tidak secara tegas menentukan apakah transaksi pihak berelasi berbahaya ataukah memberikan keuntungan bagi perusahaan dan pemegang saham (Chien dan Hsu, 2010). Terkait hal tersebut, Gordon, et al (2004) menyatakan bahwa transaksi pihak berelasi merupakan transaksi yang bersifat efisien. Berbeda dengan transaksi yang melibatkan pihak eksternal (bukan berelasi), perusahaan yang melakukan transaksi pihak berelasi akan mampu mengotimalkan alokasi sumber daya, menekan risiko yang akan terjadi, dan menurunkan biaya transaksi sehingga memberikan manfaat lebih besar bagi pemegang saham (Chen, et al., 2012). Peningkatan efisiensi terjadi pada saat dilakukan jual-beli antar pihak berelasi karena pihak-pihak berelasi mempunyai pemahaman yang lebih baik tentang aktivitas dan kebutuhan spesifik diantara perusahaan yang berelasi.

Pada sisi yang berbeda, Gordon, et al (2004) juga menyatakan bahwa transaksi pihak berelasi dapat mengakibatkan terjadinya konflik kepentingan antara tanggung jawab manajemen kepada pemegang saham dengan fungsi pengawasan yang perlu 
dilakukan. Pada satu sisi, manajemen perlu melakukan fungsi pengawasan terhadap aktivitas perusahaan bagi kepentingan seluruh pemegang saham, sementara itu pihak pengendali (mayoritas) dapat memanfaatkan kegiatan transaksi pihak berelasi untuk mengambi-alih (expropriation) hak pemegang saham minoritas (non-pengendali) melalui kegiatan tunneling (Berkman, et al., 2009; Cheung, et al, 2006). Jiang, et al (2010) menyatakan bahwa pinjam-meminjam (lending-borrowing) yang terjadi antar pihak berelasi sangat bersifat oportunistik dan dapat berfungsi mengambil alih sumber daya perusahaan. Di samping itu juga, pengambilalihan sumber daya dari pemegang saham minoritas dapat timbul dari transaksi jual-beli aset, barang dan jasa, dan pembayaran tunai kepada perusahaan terkait. Oleh sebab itu, karena sifatnya yang berulang dan juga dapat menimbulkan utang-piutang diantara pihak berelasi maka transaksi jual-beli barang dan jasa merupakan kegiatan yang paling sering dilakukan perusahaan untuk memanipulasi transaksi pihak berelasi (Habib, et al., 2017). Terjadinya pengambilalihan (expropriation) melalui kegiatan tunneling ini diindikasikan dengan nilai residual RPT-Sales yang bernilai lebih kecil dari 0 dan nilai residual RPT-Loan yang bernilai lebih besar dari 0 atau disebut dengan RPT yang bersifat abnormal (Berkman, et al., 2009; Cheung, et al., 2006; Jiang, et al., 2010).

\subsection{Political Connection dan Audit Delay}

Telah dikemukakan pada bagian sebelumnya, banyak keuntungan yang dapat diperoleh perusahaan dari adanya koneksi politis. Beberapa penelitian sebelumnya menyebutkan bahwa beberapa kemudahan yang dapat diperoleh perusahaan dengan adanya koneksi politis, diantaranya adalah kemudahan mendapatkan pinjaman (Leuz dan Oberholzer-Gee, 2006; Faccio, 2006; Boubakri et al., 2012), memperoleh pinjaman dengan biaya rendah (Houston et al., 2014), mendapatkan kontrak-kontrak pemerintah dan peraturan-peraturan yang menguntungkan (Goldman, et al., 2009). Adanya kemudahan-kemudahan tersebut menimbulkan dampak negatif dari banyak pihak terhadap perusahaan-perusahaan yang melakukan koneksi politis. Masyarakat luas menganggap bahwa perusahaan yang terkoneksi politis akan mendapatkan perlakukan istimewa jika dibandingkan dengan perusahaan yang tidak melakukan koneksi politis.

Dari hal di atas menunjukkan bahwa perusahaan yang terkoneksi secara politis kurang mendapatkan pengawasan dan pemantauan jika dibandingkan dengan perusahaan yang tidak terkoneksi (Faccio, 2006). Kondisi ini memberikan gambaran bahwa 
perusahaan terkoneksi diduga mempunyai tata kelola yang buruk, sehingga menyimpan risiko yang besar. Oleh sebab itu, dalam melakukan audit terhadap perusahaan yang terkoneksi politis auditor akan bertindak lebih hati-hati dan hal ini akan berdampak pada kebutuhan waktu audit yang lebih lama. Gul (2006) menemukan adanya peningkatan biaya audit pada perusahaan yang terkoneksi politis di Malaysia ketika terjadi krisis ekonomi. Hal ini dapat disebabkan bahwa selama masa krisis, perusahaan yang terkoneksi politis diduga terlibat dalam melakukan rekayasa laporan keuangan untuk menutupi kondisi keuangan yang sebenarnya.

Untuk meningkatkan tingkat kepercayaan masyarakat terhadap perusahaan yang terkoneksi politis, Guedhami (2014) dan Khan, et al (2016) dalam penelitiannya menemukan bahwa penggunaan auditor Big4 dan auditor spesialis industri oleh perusahaan terkoneksi politis mengalami peningkatan yang sangat besar jika dibandingkan dengan penggunaan auditor non-Big4. Di samping untuk tetap mendapatkan tingkat kepercayaan dari masyarakat, peningkatan penggunaan tersebut karena auditor Big4 dan auditor spesialis industri dianggap memiliki tingkat kompetensi yang lebih tinggi dan pada akhirnya akan dapat memperpendek rentang waktu penyampaian laporan keuangan (Guedhami, et al., 2014; Habib dan Muhammadi, 2018). Dari ungkapan diatas, maka hipotesis pertama yang akan diuji pada penelitian ini adalah: H1. Koneksi Politis (Political Connection) berpengaruh terhadap audit delay.

\subsection{Related Party Transaction, Political Connection dan Audit Delay.}

Sama halnya dengan koneksi politis, masih terjadi pendapat yang berlawanan apakah transaksi pihak berelasi memberikan keuntungan ataukah sebaliknya merugikan bagi para pemangku kepentingan perusahaan. Terlepas dari pertentangan tersebut, hasil penelitian yang dikemukan oleh Berkman, et al (2009) dan Qian, et al (2011) menunjukkan bahwa perusahaan yang terlibat dalam koneksi politis secara oportunistik cenderung menggunakan transaksi pihak berelasi. Hal ini dilakukan perusahaan untuk memberikan keuntungan bagi pemegang saham maupun pihak-pihak yang terkoneksi politis tetapi mengorbankan kepentingan pihak pemegang saham minorias. Proses ekspropriasi ini dilakukan melalui proses tunneling, yaitu suatu kegiatan yang dilakukan manajemen untuk membeli aset anak perusahaan dengan harga yang relatif murah dan menjualnya kembali kepada pihak eksternal dengan harga tinggi (Johnson, et al., 2000; Jiang, et al., 2010) dan tingginya kecenderungan perusahaan melakukan praktik-praktik 
manajemen laba (Chen, et al., 2010; Jian dan Wong, 2010). Secara khusus Aharony (2010) meneliti perusahaan yang melakukan IPO di pasar modal Cina, hasilnya menunjukkan bahwa sebagian besar perusahaan yang melakukan IPO melakukan praktik manajemen laba dengan menggunakan transaksi dengan pihak berelasi.

Kondisi tersebut sangat mungkin terjadi karena dengan kekuatan pemegang saham mayoritas, manajemen mempunyai dorongan yang kuat untuk melakukan praktik tunneling untuk mendapatkan keuntungan dan menyembunyikan kinerja yang sebenarnya dari pihak di luar perusahaan. Hal ini memberikan sinyal negatif bagi auditor ketika melakukan pekerjaan audit mereka. Auditor dituntut untuk lebih berhati-hati dalam mendapatkan bukti-bukti audit untuk kegunaan penerbitan opini mereka. Dengan demikian, auditor sangat mungkin membutuhkan waktu yang lebih lama ketika melakukan audit pada perusahaan yang terindikasi memiliki koneksi politis dan melakukan transaksi dengan pihak-pihak yang berelasi. Dari ungkapan diatas, maka hipotesis kedua yang akan diuji pada penelitian ini adalah :

H2. Transaksi pihak berelasi (Related Party Transaction) memoderasi pengaruh koneksi politis (Political Connection) terhadap audit delay.

\section{METODE PENELITIAN}

\subsection{Data dan Sampel Penelitian}

Untuk kegunaan pengujian hipotesis yang telah diajukan, data yang digunakan pada penelitian ini berhubungan dengan audit delay, political connections, related party transaction, dan data-data keuangan perusahaan manufaktur di Bursa Efek Indonesia dengan menggunakan rentang pengamatan dari tahun 2013 sampai dengan tahun 2017. Untuk mendapatkan data-data penelitian sesuai dengan rentang pengamatan tersebut, maka perusahaan manufaktur yang menjadi populasi pada penelitian ini adalah perusahaan manufaktur yang terdaftar di Bursa Efek Indonesia sampai dengan 31 Desember 2012. Pemilihan perusahaan manufaktur pada penelitian ini didasarkan pada pertimbangan karena 30\% dari perusahaan yang terdaftar di Bursa Efek Indonesia didominasi oleh perusahaan manufaktur. Di samping itu juga, pada perusahaan manufaktur mempunyai kompleksitas usaha lebih besar dibandingkan dengan sektor lainnya. 
Pada penelitian ini, pemilihan sampel dilakukan dengan menggunakan metode purposive judgement sampling, dimana sampel dipilih berdasarkan kriteria-kriteria tertentu (Sekaran, 2016), maka kriteria-kriteria yang digunakan adalah :

a. Perusahaan yang secara konsisten menggunakan mata uang rupiah dalam pelaporan keuangannya.

b. Perusahaan yang selama periode pengamatan melakukan transaksi dengan pihak-pihak berelasi.

c. Mempunyai data yang lengkap terkait dengan variabel-variabel yang digunakan dalam penelitian ini.

Atas dasar kriteria-kriteria tersebut, maka jumlah perusahaan sampel dan jumlah pengamatan (firm-year) yang digunakan pada penelitian ini seperti tersaji pada Tabel 1 berikut ini.

\section{Tabel 1}

\section{Hasil Seleksi Sampel}

\begin{tabular}{|c|c|}
\hline $\begin{array}{l}\text { Perusahaan manufaktur yang terdaftar di Bursa Efek Indonesia sampai } \\
\text { dengan } 31 \text { Desember } 2012 \\
\text { Dikurangi : }\end{array}$ & 128 \\
\hline $\begin{array}{l}\text { Perusahaan yang tidak secara konsisten menggunakan mata uang } \\
\text { rupiah dalam penyusunan laporan keuangan. }\end{array}$ & $(27)$ \\
\hline $\begin{array}{l}\text { - Perusahaan yang tidak secara konsisten melakukan transaksi } \\
\text { dengan pihak berelasi secara konsisten selama periode pengamatan }\end{array}$ & $(17)$ \\
\hline $\begin{array}{l}\text { - Perusahaan yang tidak mempunyai data lengkap selama periode } \\
\text { pengamatan }\end{array}$ & $(25)$ \\
\hline Jumlah perusahaan sampel & 59 \\
\hline Masa Pengamatan & 5 \\
\hline Jumlah Observasi (firm-year) & 295 \\
\hline
\end{tabular}

Sumber : Data yang diolah

\subsection{Definisi Variabel dan Pengukurannya}

Variabel dependen yang digunakan pada penelitian ini adalah Audit Delay (AuDel), yang menunjukkan jumlah hari yang digunakan auditor dalam melakukan penyelesaian audit. Oleh sebab itu, AuDel diukur berdasarkan jumlah hari terhitung dari akhir tahun fiskal (31 Desember) perusahaan sampai dengan dikeluarkannya laporan audit oleh kantor akuntan (Ashton, et al., 1987; Bamber, et al., 1993; Habib dan Bhuiyan, 2011; Habib dan Muhammadi, 2018). 
Penelitian ini menggunakan polical connection (PolC) sebagai variabel independen. Pada penelitian ini, suatu perusahaan dikatakan mempunyai koneksi politis jika setidaknya terdapat satu pemegang saham, anggota dewan komisaris, dan anggota dewan direksi merupakan anggota parlemen, menteri, dan kepala pemerintah daerah atau terkait dengan politisi atau partai pada periode saat ini maupun sebelumnya (Faccio, 2006; Adhikari, et al., 2006; Habib dan Muhammadi, 2018). Variabel political connection diukur dengan memberi nilai 1 jika perusahaan terlibat dalam koneksi politis, dan nilai 0 jika tidak terjadi koneksi politis.

Selain menggunakan audit delay (AuDel) dan political connection (PolC) sebagai variabel dependen dan independen, penelitian ini juga menggunakan related party transaction (RPT) sebagai variabel pemoderasi. Seperti telah dikemukakan pada bagian sebelumnya, RPT dapat dibagi ke dalam RPT-Sales dan RPT-Loan. Kedua RPT tersebut dapat bersifat positif (normal) dan bersifat negatif (abnormal). Mengikuti Jian dan Wong (2010) kedua RPT tersebut diukur dengan tahapan sebagai berikut :

1. Menentukan rasio RPT-Sales dan RPT-Loan, yang dihitung dengan cara :

- RPT-Sales merupakan pembagian penjualan yang berasal transaksi penjualan yang berelasi dengan total pendapatan perusahaan.

- RPT-Loan merupakan pembagian dari selisih RP-Lending dengan RP-Borrowing dengan total aktiva.

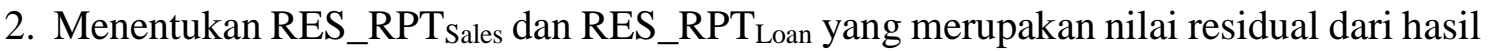
regresi kedua RPT, dengan ukuran perusahaan (SIZE), rasio utang (LEV), dan pertumbuhan perusahaan (GROWTH) dengan persamaan regresi berikut ini :

- RPT-Sales $=\alpha+\beta_{1}$ SIZE $_{i, t}+\beta_{2}$ LEV $_{i, t}+\beta_{3}$ GROWTH $_{i, t}+\varepsilon_{i, t}$

- RPT-Loan $=\alpha+\beta_{1}$ SIZE $_{i, t}+\beta_{2}$ LEV $_{i, t}+\beta_{3}$ RROWTH $_{i, t}+\varepsilon_{i, t}$

Jika RES_RPT Sales bernilai lebih kecil dari 0, maka RPT-Sales tersebut bersifat abnormal, sedangkan untuk RES_RPT Loan jika bernilai lebih besar dari 0, maka RES_RPT Loan bersifat abnormal.

Di samping ketiga kelompok variabel di atas, penelitian ini juga menyertakan beberapa variabel kontrol untuk mengendalikan karakteristik spesifik perusahaan yang diduga ikut mempengaruhi audit delay, yaitu : 
- SIZE, merupakan ukuran perusahaan yang diproksikan oleh logaritma natural dari total Aset perusahaan $i$ pada tahun $t$.

- LEV, merupakana rasio utang perusahaan $i$ pada tahun $t$, yang dihitung sebagai penjumlahan dari utang jangka pendek perusahaan $i$ pada tahun $t$ dan utang jangka panjang perusahaan $i$ pada tahun $t$ diskalakan dengan total aset perusahaan $i$ pada tahun $t$.

- GROWTH, merupakan tingkat pertumbuhan perusahaan yang diproksikan oleh tingkat pertumbuhan aktiva perusahaan i pada periode $t$.

\subsection{Model Penelitian}

Pada bagian sebelumnya telah dikemukakan bahwa penelitian ini dilakukan untuk menguji bahwa variabel political connection (PolC) akan memberikan pengaruh terhadap audit delay (AuDel) dan variabel RPT-Sales dan RPT-Loan memoderasi pengaruh political connection (PolC) terhadap audit delay (AuDel). Kedua hipotesis tersebut diuji dengan menggunakan alat uji analisis regresi berganda.

Untuk kegunaan pengujian hipotesis pertama, yaitu political connection (PolC) berpengaruh terhadap audit delay (AuDel), model penelitian yang digunakan adalah :

$$
\mathrm{AuDel}_{i, t}=\alpha_{1}+\beta_{1} \text { PolC }_{i, t}+\beta_{2} \mathrm{SIZE}_{i, t}+\beta_{3} \mathrm{LEV}_{i, t}+\beta_{4} \mathrm{GROWTH}_{i, t}+\varepsilon_{i, t}
$$

Selanjutnya, untuk kegunaan pengujian hipotesis kedua, yaitu kedua RPT memoderasi pengaruh political connection (PolC) terhadap audit delay (AuDel), model penelitian yang digunakan adalah :

$$
\begin{aligned}
& A u D e l_{i, t}=\alpha_{1}+\beta_{1} P_{\text {PolC }}, t+\beta_{2} \text { PolC } * R E S \_R P T_{\text {Sales }}+\beta_{3} P o l C * R E S \_R P T_{\text {Loan }}+ \\
& \beta_{4} \mathrm{SIZE}_{i, t}+\beta_{5} L E V_{i, t}+\beta_{6} \mathrm{GROWTH}_{i, t}+\varepsilon_{i, t}
\end{aligned}
$$

Dimana :

AuDel $_{i, t} \quad$ merupakan jumlah hari yang digunakan auditor dalam menyelesaikan proses akhir audit perusahaan $i$ pada tahun $t$

PolC $_{i, t} \quad$ merupakan variabel dummy yang diberi nilai 1 jika perusahaan $i$ pada tahun $t$ melakukan political connection, dan 0 jika sebaliknya. 
RES_RPTSales merupakan nilai residual dari related part transacton Sales perusahaan $i$ pada tahun $t$.

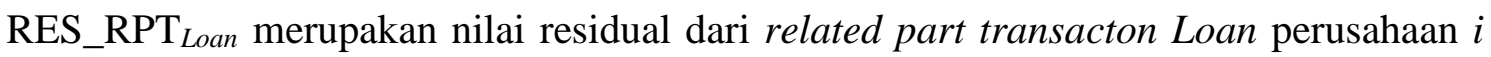
pada tahun $t$.

$\mathrm{SIZE}_{i, t} \quad$ merupakan ukuran perusahaan $i$ pada tahun $t$.

$\mathrm{LEV}_{i, t} \quad$ merupakan Leverage perusahaan perusahaan $i$ pada tahun $t$.

$\mathrm{GROWTH}_{i, t}$ merupakan pertumbuhan perusahaan perusahaan $i$ pada tahun $t$.

\section{HASIL PENELITIAN DAN DISKUSI}

\subsection{Hasil Penelitian}

\subsubsection{Statistik Deskriptif}

Berdasarkan hasil pengolahan data yang telah dilakukan, hasil statistik deskriptif untuk keseluruhan variabel yang digunakan pada penelitian ini tersaji pada Tabel 2 berikut ini :

Tabel 2

Statistik Deskriptif

\begin{tabular}{|c|c|c|c|c|c|}
\hline \multicolumn{6}{|c|}{ Panel A } \\
\hline Variabel & $\mathbf{N}$ & Minimum & Maximum & Mean & $\begin{array}{c}\text { Std. } \\
\text { Deviation }\end{array}$ \\
\hline AuDel & 295 & 44 & 166 & 76.67 & 15,637 \\
\hline RES_RPT $T_{\text {Sales }}$ & 295 & $-0,8837$ & 1,1511 & 0,0000 & 0,4893 \\
\hline RES_RPT Loan & 295 & $-0,1429$ & 0,0927 & 0,0000 & 0,0262 \\
\hline SIZE & 295 & 99,922 juta & $\begin{array}{r}295.646 .000 \\
\text { juta }\end{array}$ & $\begin{array}{r}11.957 .583 \\
\text { juta }\end{array}$ & $\begin{array}{r}34.490 .486 \\
\text { juta }\end{array}$ \\
\hline LEV & 295 & 0,0004 & 1,5711 & 0,4867 & 0.2471 \\
\hline GROWTH & 295 & $-0,4770$ & 1,130 & $-0,1269$ & 0,1838 \\
\hline \multicolumn{6}{|c|}{ Panel B } \\
\hline \multicolumn{4}{|c|}{ Tahun } & $\begin{array}{c}\text { Political } \\
\text { Connection }\end{array}$ & Persentase \\
\hline \multicolumn{4}{|c|}{2013} & 12 & $20,33 \%$ \\
\hline \multicolumn{4}{|c|}{2014} & 12 & $20.33 \%$ \\
\hline \multicolumn{4}{|c|}{2015} & 13 & $22,03 \%$ \\
\hline \multicolumn{4}{|c|}{2016} & 13 & $22,03 \%$ \\
\hline
\end{tabular}




\begin{tabular}{|l|l|l|}
\hline \multicolumn{1}{|c|}{2017} & 13 & $22,03 \%$ \\
\hline \multicolumn{1}{|c|}{ Total } & 63 & $21.35 \%$ \\
\hline AuDel = Audit Delay & & \\
PolC = Political Connections & & \\
RES_RPT Sales = Related Party Transaction-Sales & & \\
RES_RPT & \\
SIZE = Related Party Transaction-Loan & \\
LEV = Leveran Perusahaan & & \\
GROWTH = Pertumbuhan Perusahaan & & \\
\hline
\end{tabular}

Sumber : Hasil pengolahan data

Tabel 2 di atas, melaporkan hasil statistik deskriptif untuk seluruh variabel penelitian yang digunakan pada penelitian ini. Pada Panel A menunjukkan bahwa ratarata audit delay (AuDel) adalah sebesar 76. Nilai maksimum audit delay sebesar 166 hari hanya terjadi pada satu perusahaan, sedangkan secara mayoritas perusahaan sampel (45 perusahaan) pada penelitian mengalami audit delay berkisar antara 70-88 hari. Jika dibandingkan dengan batasan maksimum yang ditetapkan oleh BAPEPAM bahwa selambat-lambatnya laporan audit harus disampaikan 90 hari setelah tutup buku, maka dapat disimpulkan bahwa audit delay selama periode pengamatan cenderung panjang. Untuk nilai RES_RPTSales, mempunyai nilai rata-rata sebesar 0.0000 mendekati nilai minimum sebesar $-0,8837$. Hal ini ditunjukkan bahwa sebanyak 31 perusahaan sampel (dari total 59 perusahaan) yang mempunyai nilai RES_RPT ${ }_{\text {Sales }}$ di bawah $0(<0)$. Hal ini menunjukkan bahwa perusahaan sampel cenderung melakukan transaksi penjualan berelasi yang bersifat abnormal. Kondisi yang berbeda ditunjukkan oleh RES_RPT loan.

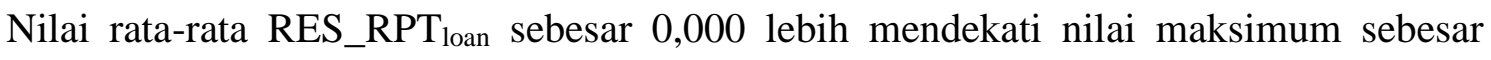
0,0927. Hal ini juga ditunjukkan pula dari banyaknya perusahaan (39 perusahaan) yang mempunyai nilai RES_RPT ${ }_{\text {loan }}$ di atas $0(>0)$. Hal ini menunjukkan bahwa perusahaan sampel pada penelitian ini cenderung melakukan transaksi utang berelasi yang bersifat abnormal. Untuk ketiga variabel kontrol yang digunakan, yaitu SIZE, LEV, dan GROWTH masing-masing mempunyai nilai rata-rata sebesar Rp 11.957.583 juta, 0,4867, dan -0,1269. Jika dibandingkan dengan rata-rata masing-masing variabel kontrol, SIZE perusahaan lebih mendekati nilai minimum sebesar Rp 99,922 juta. Hal ini menunjukkan bahwa SIZE perusahaan sampel cenderung rendah. Untuk nilai rata-rata LEV mendekati nilai maksimum (tanpa perusahaan yang mengalami defisiensi modal) sebesar 0,475 . Hal ini menunjukkan bahwa perusahaan sampel mempunyai utang yang cukup besar 
dibandingkan dengan total aset yang ada. Terkait dengan GROWTH, nilai rata-rata perusahaan sampel cenderung mendekati nilai minimum $(-0,4770)$. Hal ini menunjukkan bahwa selama periode pengamatan, perusahaan sampel mengalami penurunan pertumbuhan.

Panel B menyajikan statistik deskriptif dari variabel political connection (PolC) yang diukur dengan menggunakan dummy dari perusahaan yang mempunyai koneksi politis. Dari total 295 pengamatan, terdapat 63 pengamatan $(21,35 \%)$ yang terindikasi melakukan koneksi politis. Secara rinci disajikan pada Panel B, dari 59 perusahaan sampel terdapat 12 hingga 13 perusahaan atau berkisar antara 20\% hingga 22\% perusahaan sampel yang melakukan koneksi politis. Hal tersebut menunjukkan bahwa perusahaan sampel yang melakukan koneksi politis cenderung sedikit. Koneksi politis yang terjadi pada perusahaan sampel umumnya didominasi oleh adanya politisi (baik sebagai anggota parlemen maupun sebagai anggota salah satu partai) yang menjabat sebagai salah satu pemegang saham, anggota dewan komisaris atau anggota dewan direksi.

\subsubsection{Hasil Pengujian Hipotesis 1}

Seperti telah dikemukan pada bagian sebelumnya, hipotesis 1 dimaksudkan untuk melakukan pengujian bahwa political connection (PolC) berpengaruh terhadap audit delay. Hasil pengujian terhadap hipotesi 1 disajikan pada Tabel 3 berikut ini :

Tabel 3

\section{Hasil Pengujian 1}

$$
\left(\mathrm{AuDel}_{i, t}=\alpha_{1}+\beta_{1} \text { PolC }_{i, t}+\beta_{2} \mathrm{SIZE}_{i, t}+\beta_{3} L E V_{i, t}+\beta_{4} \mathrm{GROWTH}_{i, t}+\varepsilon_{i, t}\right)
$$

\begin{tabular}{|l|c|r|}
\hline \multirow{2}{*}{} & \multicolumn{2}{|c|}{ AuDel } \\
\cline { 2 - 3 } & $\begin{array}{c}\text { Koefisie } \\
\mathrm{n}\end{array}$ & \multicolumn{1}{c|}{ Signifikansi } \\
\hline PolC & 0,067 & $0.003^{*}$ \\
\hline SIZE & 0,010 & $0.085^{* * *}$ \\
\hline LEV & 0,132 & $0.001 * *$ \\
\hline GROWTH & 0.019 & 0.264 \\
\hline
\end{tabular}




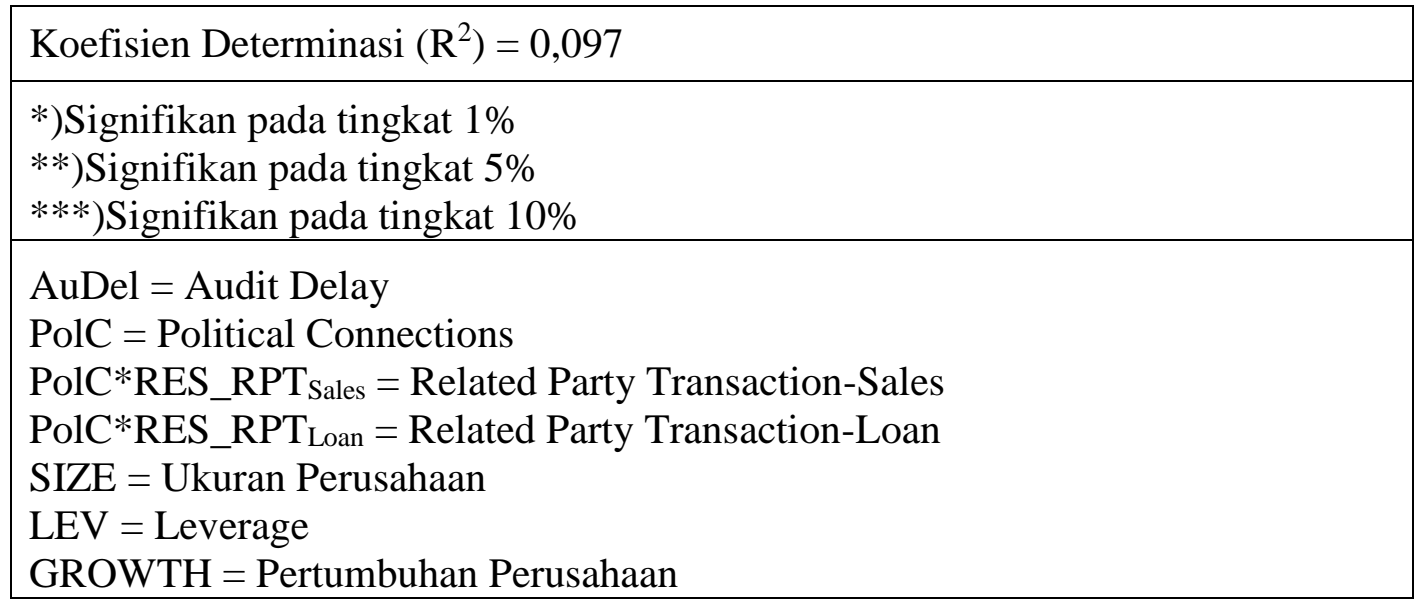

Sumber : Hasil pengolahan data

Tabel 3 di atas menunjukkan bahwa nilai signifikansi variabel PolC (Political Connection) sebesar 0,003 lebih kecil dari tingkat alpha $(\alpha)$ sebesar 0,01. Disamping itu juga, koefisien PolC menunjukkan nilai koefisien positif sebesar 0,067. Hasil ini menunjukkan mendukung hipotesis 1 bahwa Political Connection (PolC) berpengaruh secara positif dan signifikan terhadap audit delay (AuDel). Hal ini dapat disimpulkan di mana hasil pengujian mendukung argumen bahwa political connection akan meningkatkan lamanya auditor dalam melakukan penyelesaian proses audit yang dilakukan. Hasil pengujian ini menunjukkan hasil yang berbeda dengan hasil penelitian yang dilakukan oleh Habib dan Muhammadi (2018), yang menunjukkan audit delay yang lebih pendek. Hal ini disebabkan pada penelitian yang dilakukan oleh Habib dan Muhammadi (2018) lebih dititik beratkan pada penggunaan auditor Big4 dalam mengaudit perusahaan yang terkoneksi politis.

Hasil lain yang ditunjukkan oleh Tabel 3 adalah variabel kontrol SIZE dan LEV menunjukkan koefisien positif dan signifikan (pada tingkat signifikansi masing sebesar $10 \%$ dan 5\%). Hal ini menunjukkan bahwa semakin besar ukuran perusahaan (SIZE) dan tingkat utang (LEV) akan dapat mempengaruh lamanya auditor dalam menyelesaikan proses audit. Untuk variabel kontrol tingkat pertumbuhan perusahaan (GROWTH) tidak memberikan pengaruh terhadap lamanya auditor dalam menyelesaikan proses audit. Hal dapat disebabkan perusahaan sampel pada penelitian ini cenderung mengalami penurunan pertumbuhan.

Di samping itu juga, besaran koefisien determinasi $\left(\mathrm{R}^{2}\right)$ menunjukkan nilai sebesar 0,097. Hal ini menunjukkan bahwa political connection (PolC) bersama-sama dengan variabel kontrol yang digunakan (SIZE, LEV, dan GROWTH) mampu 
meningkatkan Audit Delay (AuDel) sebesar 9,70\% dan sisanya (sebesar 90,30\%) sangat dipengaruhi oleh variabel lainnya yang tidak diteliti dalam penelitian ini.

\subsubsection{Hasil Pengujian Hipotesis 2}

Hipotesis 2 yang diajukan pada penelitian ini adalah related party transaction (RPT) mampu memoderasi pengaruh political connection (PolC). Untuk kegunaan pengujian hipotesis 2, peneliti memasukan variabel RPT (RES_RPTSales dan RES_RPT Loan$_{\text {) }}$ sebagai variabel moderasi ke dalam persamaan 3, sehingga model penelitian yang digunakan untuk pengujian hipotesis 2 dilakukan dengan menggunakan persamaan 4. Hasil pengujian terhadap hipotesis 2 disajikan pada Tabel 4.

Dari Tabel 4 di bawah menunjukkan bahwa secara keseluruhan menunjukkan hasil yang tidak berbeda dengan hasil pengujian hipotesis 1. Variabel Political Connection (PolC) tetap menunjukkan nilai koefisien yang positif dan nilai signifikansinya (0.056) tetap lebih kecil dari nilai alpha $(\alpha=0,05)$. Variabel moderasi RPT (RES_RPT Sales dan RES_RPT Loan $)$ menunjukkan bahwa nilai koefisien masing-masing bersifat positif $(0,132$ dan 2,273) dengan nilai signifikansi masing-masing sebesar 0,016 dan 0,037 yang lebih kecil dari nilai alpha $(\alpha=0,05)$.

\section{Tabel 4}

\section{Hasil Pengujian 2}

$\left(\right.$ AuDel $_{i, t}=\alpha_{1}+\beta_{1}$ PolC $_{i, t}+\beta_{2}$ PolC $* R E S \_R P T_{\text {Sales }}+\beta_{3}$ PolC $* R E S \_R P T_{\text {Loan }}+$ $\left.\beta_{4} S_{S I Z E_{i, t}}+\beta_{5} L E V_{i, t}+\beta_{6} G R O W T H_{i, t}+\varepsilon_{i, t}\right)$

\begin{tabular}{|c|c|c|}
\hline & \multicolumn{2}{|c|}{ AuDel } \\
\hline & Koefisien & Signifikansi \\
\hline PolC & 0,056 & $0.002^{* *}$ \\
\hline PolC*RES_RPT Sales & 0,132 & $0,016^{* * *}$ \\
\hline PolC*RES_RPT ${ }_{\text {Loan }}$ & 2,273 & $0,037 * *$ \\
\hline SIZE & 0,010 & $0.031 * *$ \\
\hline LEV & 0,123 & $0.000^{*}$ \\
\hline GROWTH & 0.010 & 0.444 \\
\hline \multicolumn{3}{|l|}{ Koefisien Determinasi $\left(\mathrm{R}^{2}\right)=0,172$} \\
\hline $\begin{array}{l}\text { *)Signifikan pada tingkat } 1 \% \\
\text { **)Signifikan pada tingkat 5\% } \\
* * *) \text { Signifikan pada tingkat } 10 \%\end{array}$ & & \\
\hline
\end{tabular}




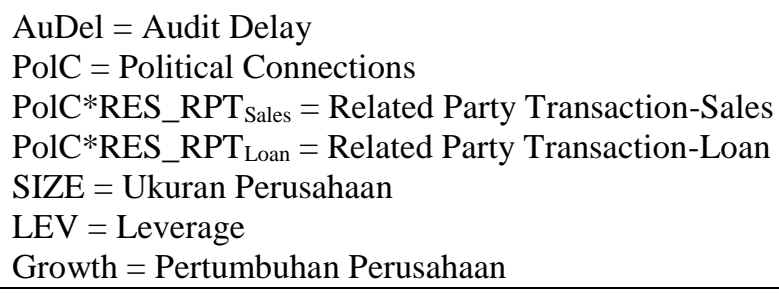

Sumber : Hasil pengolahan data

Artinya, perusahaan yang terlibat RPT abnormal secara signifikan akan ikut memperkuat pengaruh Political Connection (PolC) terhadap Audit Delay (AuDel). Di samping itu juga, dari hasil di atas menunjukkan bahwa $\mathrm{RPT}_{\text {Loan }}$ memberikan pengaruh yang lebih besar terhadap peningkatan audit delay. Secara keseluruhan hasil ini mampu mendukung hipotesis 2 yang penulis ajukan bahwa related party transaction mampu memoderasi pengaruh Political Connection terhadap Audit Delay. Artinya, dengan adanya transaksi pihak berelasi semakin memperpanjang terjadinya audit delay.

Hasil lain yang ditunjukkan oleh variabel kontrol, menunjukkan kondisi yang tidak terlalu berbeda seperti yang ditunjukkan pada hasil sebelumnya (hasil pengujian hipotesis 1). Variabel SIZE dan LEV tetap menunjukkan koefisien positif (masingmasing sebesar 0,010 dan 0,123) dengan nilai signifikansi masing-masing sebesar 0.031 dan 0.000 lebih kecil dari nilai alpha $(\alpha=0,05$ dan 0,001$)$. Konsisten dengan pengujian hipotesis pertama, bahwa perusahaan dengan ukuran (SIZE) dan tingkat utang yang besar mempunyai kompleksitas dan risiko yang lebih besar, sehingga akan membuat auditor lebih lama dalam melakukan penyelesaian proses audit. Tingkat pertumbuhan perusahaan (GROWTH) tetap tidak memberikan pengaruh terhadap lamanya auditor dalam menyelesaikan proses audit.

Besaran koefisien determinasi $\left(\mathrm{R}^{2}\right)$ pada pengujian hipotesis 2 menunjukkan nilai sebesar 0.172. Hasil ini menunjukkan bahwa penggunaan variabel moderasi RPT (RES_RPTSales dan RES_RPT Loan) bersama-sama dengan variabel utama political connection dan variabel kontrol yang digunakan (SIZE, LEV, dan GROWTH) mampu meningkatkan Audit Delay (AuDel) sebesar 17,20\% dan sisanya (sebesar 82,8\%) sangat dipengaruhi oleh variabel lainnya. Di samping itu juga, dengan menggunakan variabel moderasi RPT (RES_RPT $T_{\text {Sales }}$ dan RES_RPT $T_{\text {Loan }}$ ) koefisien determinasi $\left(\mathrm{R}^{2}\right)$ mengalami peningkatan sebesar 7,5\%. Artinya, bahwa RPT mampu memperkuat pengaruh political connection (PolC) terhadap audit delay (AuDel). 


\subsection{Diskusi}

Seperti telah disajikan pada hasil pengujian hipotesis 1 , hasil pengujian menunjukkan konsisten dengan hipotesis yang diajukan pada penelitian ini. Artinya, perusahaan yang terlibat dalam koneksi politis (political connection) secara signifikan berpengaruh positif terhadap audit delay. Perusahaan yang memiliki koneksi politis pada setiap tahun pengamatan cenderung mengalami audit delay yang panjang, karena dengan adanya koneksi politis tersebut perusahaan akan mendapatkan beberapa keuntungan dalam memperlancar bisnis perusahaan. Namun, koneksi politis cenderung dimanfaatkan oleh perusahaan sebagai cara untuk menutupi kecurangan yang dilakukan. Perusahaan yang memiliki koneksi politis umumnya memiliki pengendalian dan pemantauan yang rendah (Faccio, 2006) sehingga cenderung untuk melakukan tindak kecurangan. Selain itu, perusahaan yang terlibat koneksi politis memperoleh keuntungan dari koneksi tersebut berupa jaminan perlindungan dari pemerintah (Faccio, 2006). Adanya kecurangan yang ditutupi oleh perusahaan yang terlibat koneksi politis mengakibatkan auditor sulit untuk menelusuri transaksi-transaksi ataupun kegiatan yang mengandung unsur kecurangan, sehingga membutuhkan waktu yang lebih lama untuk menyelesaikan proses audit. Hal ini menyebabkan terjadinya audit delay yang lebih lama.

Pengujian hipotesis 2 menunjukkan bahwa dengan digunakannya transaksi dengan pihak yang berelasi memperkuat pengaruh political connection terhadap audit delay. Perusahaan yang terkoneksi politis umumnya cenderung melakukan transaksi pihak berelasi. Kecenderungan perusahaan yang terkoneksi politis melakukan transaksi dengan pihak-pihak berelasi dapat disebabkan untuk memberikan keuntungan bagi para pemegang mayoritas dan pihak-pihak yang terkoneksi politis agar tetap menjaga hubungan diantara mereka. Peningkatan hubungan yang baik tersebut berfungsi bagi perusahaan untuk mendapatkan akses yang dibutuhkan dan terutama mendapatkan jaminan perlindungan hukum, sehingga tetap menjaga stabilitas usaha perusahaan. Di samping itu juga, dengan melakukan transaksi dengan pihak yang berelasi memungkinkan perusahaan melakukan proses ekspropriasi melalui kegiatan tunneling demi kepentingan pihak pemegang saham mayoritas tetapi mengorbankan pihak pemegang saham minoritas. Hal tersebut menunjukkan bahwa transaksi dengan pihakpihak berelasi banyak menyimpan unsur negatif bagi kepentingan secara umum. Oleh sebab itu, kondisi ini memberikan sinyal negatif bagi auditor dalam melakukan pekerjaan 
audit yang dilakukan. Auditor akan lebih berhati-hati dalam melakukan pengumpulan bukti-bukti pemeriksaan dan tidak menutup kemungkinan akan memperluas ruang lingkup auditnya. Dengan demikian, auditor akan membutuhkan waktu yang lebih lama dalam melakukan proses penyelesaian audit yang mereka lakukan.

\section{KESIMPULAN, IMPLIKASI, DAN KETERBATASAN}

Penelitian ini dilakukan untuk melakukan pengujian terhadap pengaruh adanya koneksi politis (political connection) terhadap audit delay dan dampak penggunaan transaksi pihak berelasi (related party transaction) dalam memoderasi pengaruh adanya koneksi politis (political connection) terhadap audit delay. Berdasarkan pengujian yang dilakukan menunjukkan bahwa (1) adanya koneksi politis (political connection) memberikan pengaruh terhadap semakin lamanya masa penyampaian laporan audit (audit delay), dan (2) transaksi pihak berelasi (related party transaction) semakin meningkatkan pengaruh (political connection) terhadap audit delay. Hasil pengujian pertama memberikan makna bahwa koneksi politik (political connection) mengindikasikan kemungkinan terjadinya kecurangan-kecurangan sehingga membuat auditor semakin berhati-hati dalam melakukan proses audit yang dilakukan. Keadaan ini mengakibatkan semakin lamanya masa penyampaian laporan hasil audit. Sama halnya dengan pengujian pertama, hasil pengujian kedua menunjukkan tingginya tingkat risiko bisnis yang disebabkan adanya transaksi pihak berelasi (related party transaction) pada perusahaan yang terlibat dalam koneksi politis dan membuat auditor lebih sensitif terhadap informasi yang akan dikumpulkan, sehingga semakin meningkatkan lamanya masa penyampaian laporan audit. Hal ini disebabkan bahwa transaksi pihak berelasi (related party transaction) pada perusahaan sampel cenderung mengarah pada transaksi pihak berelasi yang bersifat abnormal (mengindikasikan adanya penyalahgunaan transaksi pihak berelasi).

Penelitian ini memberikan implikasi bahwa auditor harus lebih seksama dalam melakukan proses audit pada perusahaan yang terkoneksi secara politis dan melakukan transaksi pihak berelasi. Walaupun koneksi politis dan transaksi pihak berelasi tidak selamanya memberikan indikasi negatif, tetapi hal tersebut tetap memberikan sinyal negatif. Oleh sebab itu, hendaknya kantor akuntan memberikan penugasan kepada auditor yang lebih berpengalaman dan auditor yang mempunyai spesialis di bidang tertentu. 
Keterbatasan penelitian ini pada sampel penelitian yang terbatas pada sektor manufaktur, sehingga mempengaruhi generalisasi hasil penelitian. Oleh sebab itu, bagi kepentingan penelitian selanjutnya disarankan untuk memperluas kelompok industri yang digunakan sebagai sampel penelitian. Di samping itu juga, bagi penelitian selanjutnya disarankan untuk menggunakan indikator lain dalam mengukur transaksi pihak berelasi (related party transaction), seperti transaksi pembelian yang berelasi dan jaminan berelasi.

\section{DAFTAR PUSTAKA}

Adhikari, Ajay, Chek Derashid dan Hao Zhang. 2006. Public Policy, Political Connections And Effective Tax Rates: Longitudinal Evidence From Malaysia. Journal of Accounting and Public Policy, Vol 25, pp. 574-995.

Aharony, Joseph, Jiwei Wang, dan HongqiYuan. 2010. Tunnelling As An Incentive For Earnings Management During The IPO Process In China, Journal of Accounting and Public Policy, Vol. 29 No. 1, pp. 1-26.

Arens, Alvin A., Randal J. Elder, Mark S. Beasley, dan Chris Hogan. 2017. Auditing And Assurance services : An Integrated Approach. Edisi 16. Boston : Pearson Education, Inc.

Ashton, R. H., Willingham, J. J. dan Elliott, R. K. 1987. An Empirical Analysis Of Audit Delay. Journal of Accounting Research. Vol. 25 No. 2, pp. 275-292.

Ashton, Robert H., R.H., John J. Willingham, dan Robert K. Elliott. 1987. An Empirical Analysis Of Audit Delay. Journal of Accounting Research, Vol. 25 No. 2, pp. 275292.

Bamber, E. M., Bamber, L. S. dan Schoderbek, M. P. 1993. Audit Structure And Other Determinants Of Audit Report Lag: An Empirical Analysis. Auditing: A Journal of Practice \& Theory. Vol. 2, No.1, pp. 1-23.

Bamber, E. Michael, Linda Smith Bamber, dan Michael P Schoderbek. 1993. Audit Structure And Other Determinants Of Audit Report Lag: An Empirical Analysis, AUDITING: A Journal of Practice \& Theory, Vol. 2 No. 1, pp. 1-23.

Bapepam LK. 2003. Keputusan Ketua Badan Pengawas Pasar Modal dan Lembaga Keuangan Nomor: Kep-36/PMK/2003, tentang Kewajiban Penyampaian Laporan Keuangan Berkala. Jakarta.

Berkman, Henk, Rebel A. Cole, dan Lawrence J. Fu. 2009. Expropriation Through Loan Guarantees To Related Parties: Evidence From China. Journal of Banking and Finance, Vol. 33 No. 1, pp. 141-156.

Chaney, Paul K., Mara Faccio, dan David Parsley. 2011. The Quality Of Accounting Information In Politically Connected Firms. Journal of Accounting and Economics, Vol. 51, Issues 1-2, pp. 58-76. 
Chen, Jean Jinghan, Peng Cheng, dan Xinrong Xiao. 2010. Related Party Transactions As A Source Of Earnings Management, Applied Financial Economics, Vol. 21 No. 3, pp. 165-181.

Chen, Shenglan, Kun Wang, dan Xiaoxue Li. 2012. Product Market Competition, Ultimate Controlling Structure And Related Party Transactions. China Journal of Accounting Research, Vol. 5 No. 4, pp. 293-306.

Cheung, Yan-Leung, P. Raghavendra Rau, dan Aris Stouraitis. 2006. Tunneling, Propping, And Expropriation: Evidence From Connected Party Transactions In Hong Kong. Journal of Financial Economics, Vol.82, Issue 2, pp. 343-386.

Chien, Chu-Yang dan Joseph C. S. Hsu. 2010. The Role Of Corporate Governance In Related Party Transactions. SSRN eLibrary.

Choi, Jay Pil, \& Marcel Thum, M. 2009. The Economics Of Politically-Connected Firms. International Tax and Public Finance, 16, pp. 605-620.

Christian, Leuz, dan Felix Oberholzer-Gee. 2006. Political Relationships, Global Financing, And Corporate Transparency: Evidence From Indonesia. Journal of Financial Economics, Vol. 81 No. 2, pp. 411-439.

Cohen, Jeffrey R., dan Dennis M. Hanno. 2000. Auditors' Consideration Of Corporate Governance And Management Control Philosophy In Preplanning And Planning Judgments. AUDITING: A Journal of Practice and Theory, Vol. 19 No. 2, pp. 133146.

Durand, Giselle. 2019. The Determinants Of Audit Report Lag: A Meta-Analysis. Managerial Auditing Journal, Vol. 34 Issue: 1, pp.44-75.

Faccio, M. 2006. Politically connected firms. The American Economic Review, Vol. 96 No. 1, pp. 369-386.

Gordon, Elizabeth. A., Elaine Henry, dan D. Palia. 2004. Related Party Transactions And Corporate Governance. Advances in Financial Economics, Vol. 9, pp 1-27.

Guedhami, Omrane, Jeffrey A. Pittman, dan Walid Saffar. 2014. Auditor Choice In Politically-Connected Firms. Journal of Accounting Research, 52(1), 107-162.

Gul, Ferdinand A. 2006. Auditors' Response To Political Connections And Cronyism In Malaysia. Journal of Accounting Research, Vol. 44 No. 5, pp. 931-963.

Habib, Ahsan dan Md. Borhan Uddin Bhuiyan. 2011. Audit Firm Industry Specialization And The Audit Report Lag. Journal of International Accounting, Auditing and Taxation, Vol. 20 No. 1, pp. 32-44.

Habib, Ahsan, Abdul Haris Muhammadi, dan Haiyan Jiang. 2017. Political Connections and Related Party Transactions: Evidence from Indonesia. The International Journal of Accounting, Vol. 52 Issue: 1, pp. 45-63.

Habib, Ahsan dan Abdul Haris Muhammadi. 2018. Political Connections And Audit Report Lag: Indonesian Evidence. International Journal of Accounting \& Information Management, Vol. 26 Issue: 1, pp.59-80.

Houston, Joel F., Liangliang Jiang, Chen Lin, dan Yue Ma. 2014. Political Connections And The Cost Of Bank Loans. Journal of Accounting Research, Vol. 52 No. 1, pp. 193-243. 
Ikatan Akuntan Indonesia. 2018. Standar Akuntansi Keuangan. Jakarta : Ikatan Akuntan Indonesia.

Jiang, Guohua, Charles M.C.Lee, dan HengYue. 2010. Tunneling Through Intercorporate Loans: The China Experience. Journal of Financial Economics, Vol. 98, Issue 1, pp. 1-20

Johnson, Simon, Rafael La Porta, Florencio Lopez-de-Silanes, dan Andrei Shleifer. 2000. Tunneling. The American Economic Review, 90, 22-27.

Keng, I, Liu, Y. Angela, dan Lin, Wen-Yi. 2010. Related Party Transactions, Firm Performance And Control Mechanisms: Evidence From Taiwan. International Research Journal of Finance and Economics ISSN 1450-2887 Issue 35.

Khan Arifur, Dessalegn Getie Mihret, dan Mohammad Badrul Muttakin. 2016. Corporate Political Connections, Agency Costs And Audit Quality. International Journal of Accounting \& Information Management, Vol. 24 No. 4, pp. 357-374.

Li, Hongbin, Lingsheng Meng, QianWang, dan Li-An Zhou. 2008. Political Connections, Financing And Firm Performance: Evidence From Chinese Private Firms. Journal of Development Economics, 87, 283-299.

Miettinen, T., \& Poutvaara, P. 2014. A Market For Connections. European Journal of Political Economy, Vol. 33, pp. 37-52.

Ming Jian, dan T. J. Wong. 2010. Propping Through Related Party Transactions. Review of Accounting Studies, Vol. 15 No. 1, pp. 70-105.

Narjess, Boubakri, Omrane Guedhami, DevMishra, dan Walid Saffar. 2012. Political Connections And The Cost Of Equity Capital. Journal of Corporate Finance, Vol. 18 No.3, pp. 541-559.

Qian, Meijun, Hongbo Pan, dan Bernard Yin Yeung. 2011. Expropriation Of Minority Interest Shareholders In Politically-Connected Firms. SSRN eLibrary.

Sekaran, Uma, dan Roger Bougie. 2016. Research Methods For Business : A SkillBuilding Approach. Edisi 7. Chichester-West Sussex : John Wiley \& Sons.

Su, Zhong-qin , Hung-gay Fung, dan Jot Yau. 2013. Political Connections And Corporate Overinvestment: Evidence From China. International Journal of Accounting and Information Management, Vol. 21 No. 4, pp. 285-296.

Wu, Wenfeng, Chongfeng Wu, dan Oliver M. Rui. 2012. Ownership And The Value Of Political Connections: Evidence From China. European Financial Management, Vol. 18, Issue 4, pp. 695-729.

Yeh, Yin-Hua, Pei-Gi Shu, danYu-Hui Su. 2012. Related-Party Transactions And Corporate Governance: The Evidence From The Taiwan Stock Market. PacificBasin Finance Journal, Vol. 20, Issue 5, pp. 755-776.

Yuki, Fukuoka. 2013. Indonesia's 'Democratic Transition' Revisited: A Clientelist Model Of Political Transition. Democratization, Vol. 20, No. 6, pp. 991 - 1013. 